\title{
Re-Configuring the New Women - Female Screenwriters and Street Films in Weimar Republic
}

\author{
JULIANE SCHOLZ, University of Leipzig
}

\section{ABSTRACT}

This article traces the history of early female screenwriters in Germany and highlights the influence of professional female screenwriter Ruth Goetz and her movie Die Dirnentragödie (also: Women without Men, 1927). It shows how the movie represented certain political, cultural and legal debates on the New Woman and reconfigured the myth by implementing ambivalent gender roles in the plot. Furthermore, the representation of the role of female sex workers in Weimar society in Weimar street films is described and the way of transforming cultural and political discourses about gender equality into silent movies is discussed. Ruth Goetz and her professional screenwriting work is revisited through the lens of New Film History and the importance of the early professional female screenwriters' contribution in Weimar cinema is underlined.

\section{KEYWORDS}

Ruth Goetz, Germany, screenwriting, film, New Woman, Weimar

\section{Introduction}

Weimar era was an embattled period, where conservative, social democrats and socialist political fractions questioned traditional and progressive political movements. It was also a time of several cultural and legal debates about gender appearance, emancipation, women's rights and female sex crimes. Weimar Republic initiated the establishment of groundbreaking women's rights, such as the right to vote and the idea of a reevaluation of gender roles by a newly expressed image of femininity through the image of an emancipated, so called New Woman. In addition, several legal reforms allowed women to attend universities and start to work in several male-dominated professions (Huerkamp 1996, 28-45, 274). By the end of the $19^{\text {th }}$ century, women could be well educated, self-sufficient and able to choose a lifestyle they preferred.

Due to the overwhelming success of the film industry and its commercialisation and rationalisation since the First World War, many women entered the field of screenwriting where they helped to shape the professional craft from an early stage in the mid-1910s (Scholz 2015, 17-25). The discourses surrounding the New Woman influenced filmmakers and their ideas of representing female characters through the aesthetics, narrative and structures of their screenplays.

This article tracks early female screenwriters and their contributions to silent movies in Germany, highlighting the influence of professional female scenarist Ruth Goetz. Along with other female writers, Goetz contributed to various genres, which were not limited by 'women' tropes. The various professional stereotypes and roles of women behind and on the screen will be outlined in this article. The films and accompanying screenplays, which reconfigured Weimar society's discourses on the idea of a New Woman in the street films, including plots focused on female sex workers, will be discussed. Furthermore, the reassurance of both the gender roles and bi-gendered normative sexual stereotypes will be argued and questioned through an analysis of Ruth Goetz's screenplay for the movie Die Dirnentragödie (1927). Also the movie reflects fights and issues of the heterogeneous first women's movement and legal, political and cultural struggles on quality (Wager 1999, 25-35; Scholz 2016, 180-192). 


\section{State of Research}

Many studies deal with Weimar expressionistic cinema of the 1920s (Korte 1978, Elsaesser 2002 \& 1999). Most media historians concentrate on famous directors like Fritz Lang, G.W. Pabst or Robert Wiene (see the contributions in Isenberg 2009), but studies on the influence and role of female screenwriters during that time are mostly a side note (Kasten 1990). Exceptions are famous screenwriter Thea von Harbou (Bruns 1995) and Leni Riefenstahl (Trimborn 2002), but they mostly were highlighted in their role during the national socialist dictatorship, not to their early contribution on silent Weimar cinema. The role of professional female filmmakers is still a fragment research topic in German film and media history.

To the contrary, screenwriting research in the United States has contributed to Gender Studies approaches by establishing the important role of female scenarists in silent cinema (Norden 1995, Francke 1994 Bielby \& Bielby 1996, N.N. 2006a; Herminghouse \& Mueller 1997). The interdisciplinary studies informed Film Studies, Sociology and the history of professions by concentrating on female actors and protagonist on and off screen. Anglo-American New Cinema History and Postcolonial Film Studies especially have established key concepts not only analysing film narrations and relying on close readings, but including various production contexts and institutional, political, economic and structural patterns of the film industry. They have also introduced postcolonial understandings of race, class and gender into film studies (Malby 2011: 4).

For the German case, these kind of historical studies are still very rare, because the importance of the Geschlechtergeschichte or gender studies has not been as influential as the Anglo-American Gender Studies and is still a very recent phenomena in German academia (Gebhardt 2006, Hagemann 2007, 194f). The idea of narrating a history on the relation of at least two sexes or genders and connecting classical social and cultural history approaches with the construction of gender representations or body image is still very new (Gebhardt 2006; Heinsohn \& Kemper 2012). Studies on Weimar Republic explained 'the failure' of the democratic system by demonstrating the influence and political impact of the middle classes and their radicalisation. Those historical attempts were widespread, but the role of women and gender as a research perspective 'excluded' women as actual active historical protagonists until the emergence of Geschlechtergeschichte (as an enhancement of Women's Studies). Those newer approaches provided several influential studies on Weimar era, where gender as a category became a focal point and women were seen as important support for the national socialist regime. The researchers tried to understand the reactionary antifeminist backslash just before national socialists took over in 1933 and rethought the role of women in the dictatorship. But those groundbreaking studies (Koonz 1976a and 1976b) were also heavily criticised as antifeminist and tendentious works by leading Women's historians themselves (Grossmann 1991). Taking a closer look at Screenwriting Studies, the emergence of screenwriting as a profession was addressed in just a few works (Kasten 1990, 43-55; Schwartz 1994, 71-84; Scholz 2014, 289-327 and Scholz 2015, 17-29). The discourse about the role of the New Woman as a cultural phenomenon in the 1920s was addressed several times in German Studies (Makela 2015, Ankrum 1995), Film Studies (Hales 2007, Kosta 1997) and Cultural Studies (Marhoefer 2011; Sharp 2004; Sutton 2011, Föllmer 2005) as well as in general historical overviews on Weimar era (Wirsching 2010; Büttner 2008; Sassenberg 2004).

\section{Ruth Goetz as Screenwriter}

Some of the earliest traceable screenplays were written by female screenwriters, like the aforementioned Ruth Goetz, Fanny Carlsen and Marie Luise Droop. Ruth Goetz's screenplays served both traditional and more emancipated gender roles. In order to exemplify and deconstruct the New Woman the movie Die Dirnentragödie $^{1}$ (Tragedy of the Street, 1927) and accompanying screenplay by Goetz, can be analysed as an

\footnotetext{
${ }^{1}$ Another possible English translation could be Tragedy of a Harlot. All film information is taken from http://www.filmportal.de and http://www.earlycinema.uni-koeln.de unless otherwise stated.
} 
example of late first wave feminist struggles. The film presents a narrative and plot, which reflects ambivalent representation of women in Weimar times. The narration contributed to broader debates and mediated discourses of traditional female stereotypes and a newly founded image of women on and off the screen.

Goetz was one of the first professional screenwriters in German film history. She began her writing career as a translator of French. Goetz published various entertaining and popular novels like Das ewige Fräulein (The Eternal Fräulein, 1919) and soon became editor of publishing houses like Ullstein and Mosse. Since the advent of World War I, she submitted film ideas and screenplays, becoming a professional scenarist. Other early female scriptwriters in Weimar cinema included Marie Luise Droop who wrote Die Teufelsanbeter (Devil-Worshipper, 1920), Fanny Carlsen whose screenplay for the successful Gerhard Hauptmann play Der Biberpelz (The Beaver Fur, 1927) gained widespread recognition and finally Jane Beß, who wrote the script for Razzia in 1921. These women became successful screenwriters during the 'roaring twenties'; most of them co-authored or single-handedly wrote scenarios for more than fifty movies of the silent era (Weniger 2011, S. 199f).

After working for the French film producer Gaumont, Goetz moved back to Germany and worked as a fulltime screenwriter for Decla-Film in Berlin teaming up with producer Erich Pommer and director Erwin Neuß on Der Weg der Tränen (The Way of Tears, 1916). She became well known for scripting silent movies for actresses like Hedda Vernon and Asta Nielsen. Her screenplays for movies like Mouchy (1918) and Noemi, die blonde Jüdin (Noemi, the blonde Jew 1917) became silent classics. In 1918 Goetz co-authored with notorious producer and director Joe May monumental films like Die Herrin der Welt (The Ruler of the World) and the three-piece high-budget epic Veritas Vincit. Goetz contributed to various German production companies such as Ring-Film, Eiko-Film or Carl-Wilhelm-Produktion. She specialised in melodramatic and historical subjects, but most of all, she predominantly constructed plots around strong female protagonists (Scholz 2016, 180-192).

During the late 1910s and early 1920s she also worked as a journalist for fashion magazines like Modespiegel or Mode-Notizen and focused on popular 'women' topics, for instance cooking manuals and beauty guidebooks. One of her guidebooks, Lehrbuch der Schönheit (Textbook of Beauty), made numerous reissues and became a bestseller in early 1930s. The beauty guide gave tips for female lifestyle issues such as makeup tips for different shaped heads, how to brush your hair right, how to get rid of facial hair and how to hide big pores or crow's feet wrinkles. The health and beauty instructions were designed for a new kind of modern women, but also the proposed directions were designed to help older women maintain their beauty and appear younger than they actually were (Goetz \& Strassburger 1930). This was also a common narrative in the screenwriting works Goetz scripted. Goetz also wrote the famous recipe collection Kochbuch für Alle (Cooking for Everybody) in 1932 and gave styling and fashion advice in her various magazine articles (Bertschik 2005, 274). As a female freelance author, writing for different media genres, she performed various lifestyles.

I argue, Goetz added self-referential sub-texts in her screenplay, which not only deal with lost stardom of the silent movie starlets with the beginning of sound film, but also transformed the idealised New Woman into a more conservative and traditional female gender appearance by the end of the 1920s. This development became increasingly obvious since 1930 and finally led to a reactionary backslash of anti-feminist movements and buried subtle women's emancipation attempts (Maccormick 2009, 284; Büttner 2008, 254f). At the end of the 1920s, several religious, political and educational movements claimed that equality between sexes had been accomplished by the right to vote in 1918, the right to work and the right to enter universities 
and that feminist ideas and supporting minorities, outcasts or stigmatised professions like prostitutes were not needed anymore. So this first very heterogeneous social women's movement was further separated because of coverall goals and thematic issues into bourgeois' temperate, the more radical middles class and the socialist women's movement. Also studies assumed that political women activists joined the rising nationalist movement rejected feminist activities eventually (Davis 2000 \& 2007; Scheck 2004). Goetz and her screenwriting works were influenced by those changes around her and the growing women's movement ideas and struggles.

On another level, considering the movie and screenplay Die Dirnentragödie transports a stereotyped version of sexualised crimes and female delinquency by arguing women had an irrational criminalist nature, which could only be suppressed by keeping them in private or separate spheres and by supporting their 'passivity' with 'traditional' features of 'essential womanhood'. Female sex crimes were another common trope in Weimar street films. The film industry debates around medical and pseudo-scientific explanations offered an answer and 'proof' for the 'predatory' inner-self of women, which committed certain 'sex crimes' out of her emotional state and 'irrationalised' nature. The question is, if and how this can be traced in Die Dirnentragödie and how it supported an alternative expression and role of femininity and gender?

\section{(Re)-Constructing the Myth of the New Woman}

Weimar Republic yielded vast cultural and political conflicts. After the German revolution in 1918/19 traditional aristocratic elites began to vanish and bourgeois middle classes emerged (Siegrist 2003, 21-30). Educated bourgeoisie and the new stratum of Angestellte (staff employees) were established and with the inflation and economic crisis a new notion of rationalised, industrialised modernity arose (Kocka 1977, 170184). Women were still in precarious and unequal positions, especially when they belonged to the lower social stratum, but even members of the bourgeoisie suffered from the lack of gender equality. The emancipation movement was designed for white women who belonged to the middle classes or aristocratic households in urban regions.

The highly divergent women's movement supported the idea of re-shaping gender roles and stereotypes at all stakes. Most importantly, women achieved the right to vote in 1918, after that the emancipation movement frayed out and other religious, political and ideological beliefs became obvious. Therefore, the debates on the New Woman only affected some individual women's organisations and specific milieus, and cannot be seen as widespread social phenomenon. The position and social status of women depended on many factors and varied from case to case. But, the discussions on cultural patterns of several reform movements left deep traces in history in terms of political, cultural and economic transition of women's rights (Wirsching 2008, 94).

The most influential idea in mass media became the image of the New Woman as an expression of independent modern womanhood, which was heavily advertised in journals and newspapers. The New Woman was characterised by an androgynous appearance; a shorter hair-cut called Bubikopf or bob (Eton crop), spare time activities like cinema, dancing and sport clubs (mostly playing tennis). Typically younger employees (Angestellte) strove after this new ideal (Ankrum 1995, 180-182) and it was also represented by female screenwriters in the movies.

The myth of New Woman was also shaped by many beauty and life-style journals, who significantly contributed to the image of a financially independent, relaxed and androgynous woman, who was the antithesis to the 'nurturing, passive and irrational' woman of older generations (Stern 2004, 52; Sharp 2004, 122124). These images served normative gender roles and polarisation of sexes since the enlightenment and even the Weimar women's movement assimilated those stereotypes between the sexes in order to gain 
political and social recognition (Büttner 2008, 258f, Koontz 1976b). Despite several divergent emancipation movements, sexual and educational reformers fought against patriarchal repression and stereotyped gender roles (Koonz 1976s and 1976b). But, gender and women's equality was not yet achieved and the women's emancipation movement lost its influence in the late 1920s, after having reached their overall goal: the right to vote in 1918 (Büttner 2008, 258).

The urban image of a New Woman promptly became a glorified myth of Weimar era. Some historians argued that the image of the New Woman was not a widespread social phenomenon, but just a media constructed hype in a narrow milieu (Föllmer 2005, 289, Ankrum 1995, 180). It seems that androgynous, masculine and more self-aware women appeared primarily in urban spaces and were typically pictured in fashion magazines like Die Dame (Haase 2008, 28-32), but were not the characteristic representative of everyday life in rural areas and in working class households. Ursula Büttner limits the time span of this experience to the interim time of teenage girls and young adulthood, when most women were not married yet, but lived on their own and had a steady employment (Büttner 2008, 254-257). If New Woman was limited to such a short time in women's lives and was a phenomena in urbanised middle and upper classes, how could the myth persist as a dominant historical pattern and leading expression of 'modernity' and emancipation in Weimar era?

In times of gender pay gap, sexual discrimination as well as unequal marriage law, the possibility to work autonomously became a common way for educated women to achieve certain financial sovereignty and destabilise the ever-present hetero-normative patriarchy since the turn of the century (Büttner 2008, 254). Working in the film industry provided new workspaces for female novelists who entered the screenwriting profession in the first decade. Until the mid1920s screenplays could be easily written as a spare time activity even at home and the success of the new mass medium served as bread and butter for aspiring female writers, who saw themselves not as intellectual novelists, but as 'Filmarbeiterinnen' (film workers) like Thea von Harbou, as mentioned, who wrote mostly on trivial plots, which served entertaining needs (Scholz 2016, 180195).

Additional important debates in press circulated around the type of the New Woman concerned the fear for a so-called 'masculinisation' and blurred gender lines. A woman with trousers and shot hair, who played tennis and took part in public events, was seen as the ultimate enemy of patriarchy (Sutton 2011, 1-24). The Vermannlichungsdebatte attributed the New Woman as central focal point of changing gender roles since the end of World War I. At its peak around 1925, male women and the uprising gender confusion became an important topic of media transmitted discourse. Not only reports focused on the myths of the New Woman, but advertisements displayed smoking androgynous trouser-wearing females, which were now considered as major consumers. Some magazines even represented queer/lesbian lifestyles candidly in magazines like Die Freundin (Sutton 2004, 126-150).

But, the New Woman also meant ambivalent reflections on femininity, which supported the 'aggressive' and 'irrational' element in womanhood. Medical discourses on sex glands, hormones and passive aggressive behavior stereotyped women as femme fatale, who committed sex-crimes and lured poor and naïve men into their spider-web like Goetz did in Die Dirnentragödie (Sharp 2004 118-120). In general, it does not seem to be a proper perspective to consider the discourses on New Woman narrowly as a media event to improve the sales figures of cloths manufacturers and publishing houses. The promotion of female consumerism and comodification of products for working women was just one aspect of a very versatile discourse in the Weimar society. 
Women's movements formal legal and political equality and the idea of blurring gender roles became particularly visible in cinematic expressions during the 1920s. It looks like there is more to it than a shortlived idealised cliché. The aforementioned debates, which centered on the New Woman formed an entangled discourse, which happened to be blatantly visible and readable in (sub)-texts of street films at that time.

As for the movies and their screenwriting practice women in early silent film were extremely important, because they provided not only an anticipated female 'gaze' of characters and plot structures, but also scenarios, who were important cinematic milestones (Scholz 2016, 190-192).

\section{Die Dirnentragödie (1927) - Femme Fatales, Nurturing Woman and Sex Crimes}

In the vast amount of her movie scripts, her magazine articles and the notorious Lehrbuch der Schönheit Goetz contributed to traditional women's issues like household, beauty, health and love advice. At a first glance, all those topics do not sound emancipated or feminist at all, but her professional screenwriting career contributed to various discourses focused on the New Woman from a more traditional conservative and entertaining point of view. Moreover, Goetz's screenplay for Die Dirnentragödie contains numerous hints and links to aforementioned debates during that time.

If the image of the New Woman is ideally recaptured as a hard-working, self-conscious and independent (financial, social, and political) female, all these elements are mutually reflected in Asta Nielsen's depiction of the 44-year-old prostitute Auguste in Die Dirnentragödie. The film was directed by Bruno Rahn (18871927) and is one of the important Sittenbild of Neue Sachlichkeit (New Objectivity). Films of New Objectivity-era (1923-1930) contained expressionistic features, but relied more on social realistic aesthetics. Topics included alienation of individuals and supernatural forces beyond human control like tyranny as well as insanity, nihilism and loss of status and dignity (Aitken 2001, 53-56). Those very dark and gloomy urban street films described the hidden criminal and dangerous sides of town.

In Die Dirnentragödie, prostitute Auguste falls in love with young student Felix (Werner Pittschau), who searches for shelter in her room after running away from home. Auguste, who is aware that she cannot work on the streets any longer, thinks Felix loves her truthfully and could get her out of the brothel. Her younger roommate Clarissa (Hilde Jennings) seduces Felix knowing Auguste has feelings for him. She realises that Felix was just looking for some motherly understanding and needed a warm place. He is far more sexually attracted to younger prostitute Clarissa. Out of jealousy and envy, Auguste tells her naive pimp Anton (Oskar Homolka), that Clarissa plans to leave with their money. Out of rage, Anton kills Clarissa on the streets, but is caught by the police in the nearby bar afterwards and finally confesses that Auguste instigated him to the crime. Before the police can enter the brothel room Auguste commits suicide.

Auguste is pictured as a femme fatale, who put Anton up on the murderer of Clarissa. Also the scene depicts that Auguste's former beauty is fading when she looks in a mirror and sees an old and exhausted reflection of herself. The negative stereotyped femme fatale in the characterisation of Auguste is also a representation of the negative image provided by Weimar society on prostitutes at that time. Most of the conversations between her and Clarissa centre on her teenage years and former seduction skills. Remarkably director Bruno Rahn and Ruth Goetz's screenplay depict prostitution as not something perverse or criminal, but rather as an everyday, legitimate profession.

It also provides a stereotyped plot centred on social class and gender debates, when the bourgeois aristocratic student enters the felonious and shady prostitute milieu. Those fictional narratives or plot ideas were accompanied by general social and legal developments outside the film industry, which gained legal deregulation of female prostitution in 1927. The revised Reichsgesetz zur Bekämpfung von 
Geschlechtskrankheiten (Reich Law to Combat Sexual Transmitted Diseases) promised more sexual freedom and bodily autonomy for women, because scientists argued, that prostitutes must be 'ill' or 'degenerated' psychologically and/or biologically. Simultaneously, women’s organisations and religious associations tried to help and prostitutes with counseling. The end of the decade was marked another legal deregulation, which eased paragraph 175 that criminalised homosexual encounters between men (Marhoefer 2011, 532-538). Die Dirnentragödie addressed those debates and tried to show the emotional and social deterioration of Auguste. By referring to a newspaper article in the last scene, which reports the tragedy and states the crime out of jealousy, a certain kind of link to Weimar social reality is built up. It is also most likely that the film story itself refers to an article that Ruth Goetz and Leo Heller finally adapted for the screen version.

The representation of Auguste and her decay serves as anti-thesis to cheerful and happy Clarissa. This is not only symbolised by all the glances into various mirrors or windows, but through the techniques and beauty tricks she uses to appear younger, to stop her decay, something that actress Asta Nielsen could interpret in one of her final roles. But her character is seen as an unstable femme fatale with sexual openness and criminal energy (Hales 2007, 228). Auguste is also characterised as a mother surrogate for student Felix, which she at first confuses with real sexual interest or love. Therefore, the character of Auguste combines elements of the film noir stereotypes like femme fatale (sexually active) and nurturing woman, who acts passively and is victimised by Clarissa.

Furthermore, this double representation reflects several problems that women faced at the end of the 1920's in Weimar society. In the transition period of the 1920s, more and more reactionary and conservative ideas came to surface and there was a struggle with the modern expression of the New Woman. It became obvious that the short-lived myth was challenged by conservative female stereotypes, which allowed women just to be mothers who care for the household.

Other readings of Die Dirnentragödie also reflect common legal debates on woman committing sex crimes and become delinquents out of jealousy and her 'irrational' and 'criminal' nature. The so-called Dirnennatur (inner whore) of women was especially popularised in magazines and newspapers like Berliner Illustrierte Zeitung, UHU and Die Dame:

Readers of popular press were taught how to identify certain 'types', especially of women, based on visual clues such as physical appearance and body language [...] This was backed by pseudo-scientific research (Sharp 204, 120).

For example, criminologist Erich Wulffen offered an explanation for the rise of female crimes in the post-war years and stated that the women's movement wanted to disturb female passivity through sexual freedom. Wulffen believed this was as an absolute danger for society, which led to women committing further sex crimes, because sexualised and 'active' women were seen as amoral predators. He preferred women to be kept in their private spheres, serving their traditional domestic roles passively to prevent an outbreak of their inner criminality (Sharp 2004, 121). It is no coincidence that Die Dirnentragödie referred to such a sex crime and focussed on a prostitute as a main character.

On the other hand, sexual reformers and socialist politicians in the early 1920s saw the New Woman as future ideal. They aimed for equality of the sexes and were in favour of greater independence and new moral standards (Sharp 2004, 123). The idea of marrying Felix was also a plan of Auguste in the Rahn's film, but she was not naïve for she anticipated that Felix might use her to get Clarissa or his bourgeois parents. Since the common way of forced marriage was more and more being replaced by companionate marriage (Büttner 2008, 254-257) during that era, the idea of marrying Felix seemed a lot more realistic for the plot as it may 
seem today. Nevertheless, Die Dirnentragödie used the idea of true love as a way for Auguste to have her last chance to escape poverty, so she utilises and rationalises the institution of marriage for her own good. Those expressions were also connected to the Weimar society and women's movement of the late 1920s, which at time was separated and no longer united. After women were acquired the right to vote in 1918, the other goals of the first wave women's movement were placed behind overall social and economic decline during the worldwide depression and withdrawal by nationalist radicalisation of middle classes.

Those debates were swiped, reflected and internalised by the plot. The focal point became the image and myth of the New Woman. Ruth Goetz scripted Die Dirnentragödie and also contributed to the common idea of depicting professional prostitution and female sex workers in social realistic movies of Weimar cinema (Wagner 2007, 11-13), which had a long tradition in cinema and reconfigured the relation between media, gender and Weimar society. Prostitutes were not only passive victims of society and abuse, but were most likely pictured as strong and self-dependent women who were looking for a social advancement by marrying. The famous street films or Dirnenfilme (prostitute films) mainly characterised lower class women on their way to escape poverty and poor life conditions (Hall 2009, 147). This prominent plot structure became heavily criticised by feminists and was later cinematically repeated in the USA with Pretty Woman (1990).

The discourse on the new women peaked in the early thirties and lead to a conservative turn, which preferred traditional gender-binary stereotypes and supported the passive and irrational emotionality in women's natures. A comeback of conventional 'feminine' appearances and the re-setting of orthodox roles for women in society also accompanied it. This turnabout to traditional role models about the differences between 'male' and 'female' justified the image of the caring, birth-giving and 'nurturing' woman who cared for the children and household, and was not interested in the double burden of family and career. Those ideas forestalled the Nazis' radicalised and perverted idea of womanhood as 'emancipated from emancipation' and as a birthing machine (Buske 2004: 89ff, Koonz 1976a; 1976b).

\section{Conclusion}

Taking everything into account, the film Die Dirnentragödie should not be reduced to an anti-feminist and deep-rooted patriarchal plot construction dooming the image of the New Woman in cinematic discourses, but credited for stirring up the debate on new women and on how female roles and expressions could conquer during Weimar era. Through and inside the film industry - with a major female audience and various female filmmakers - debates about the re-configuration of women's rights and gender roles were reflected through the street films. Those films also represented several social, political, religious and legal reforms and debates about femininity and the role of prostitution. It becomes obvious that Ruth Goetz's screenplay Die Dirnentragödie was not just another modern film classic, but a film balancing two different sides of New Women discourse in the end of the 1920s. This article has explained how different ideas of womanhood and femininity during Weimar times were constructed through mass media, through political, legal and social reforms and how the myth of the New Woman clouded strong counter-movements that finally succeeded in 1933. Goetz's film idea cannot be considered as a feminist piece of counter-cinema (Johnston 1999, 31-39), but it strived all complex questions the women's movement struggled with during the 1920's and provided an ambivalent view on female gender roles, aging and professional autonomy.

Moreover, the movie offers several conclusions on how women in everyday life, and especially female sex workers, can be narrated and characterised and how political debates and legal reforms became an important factor of transforming the image of New Woman towards more traditional gender roles and stereotypes. The film also provides a complex understanding of women's social situation and the idea of independent working women without men. An alternative distribution title listed Die Dirnentragödie as Women without Men, which also served the image of female 'masculinisation' and the criticism from reactionary bourgeoisie 
movements, which in the early 1930s became more and more anti-feminist and underlined conservative female stereotypes.

Ruth Goetz's career as a novelist and screenwriter also reflects the emergence of professional female filmmakers who became common role models in the German film industry. After the coming of sound, the number of female filmmakers declined rapidly to under 10 percent (Scholz 2016 and Kasten 1990, 45-50). Also with the coming of sound in 1928, Goetz ended her career in the German movie industry. Her last work as a screenwriter was the Asta Nielsen starring drama Die Dirnentragödie in 1927. From that time, she concentrated on her career as a novelist and journalist. After the national socialist uprising in 1933 Goetz called herself Ruth von Schüching (Goetz took the last name from her husband, Bernhard von Schüching, after their marriage in 1922), but as a Jew she was banned from work and eventually migrated to England. The national socialist dictatorship blacklisted her books and banned her from writing. She was expatriated legally on 25th May 1939 (Hepp 2985, 287), and lived in London until her death in 1965.

In general, the history of female screenwriting internationally remains a research gap. One step forward is the comprehensive handbook Women Screenwriters: An International Guide edited by Jill Nelmes and Jule Selbo, which was published in October 2015. But systematic historical studies not only on female screenwriting practice, but also in professional fields like direction, cinematography and producing in the first two decades of 20th century are still missing.

\section{References}

Aitken, I, (2001) European Film Theory and Cinema: A Critical Introduction, Bloomington: Indiana University Press

Ankrum, K. von (1995) 'Motherhood and the "New Women": Vickiv Baum's stud. chem. Helene Willfüer and Irmgard Keuns Gigli-eine von uns', Women in German Yearbook, 11, 177-188

Bertschik, J. (2005) Mode und Moderne. Kleidung als Spiegel des Zeitgeistes in der deutschsprachigen Literatur (1770-1945), Köln-Wien-Weimar: Böhlau

Bielby, D. D. and Bielby, W. T. (1996) 'Women and Men in Film: Gender Inequality among Writers in a Culture Industry', Gender and Society, 10:3, 248-270

Bruns, K. (1995) Kinomythen 1920-1945: Die Filmentwürfe der Thea von Harbou, StuttgartWeimar: Metzler

Büttner, U. (2008) Weimar: Die überforderte Republik 1918-1933, Stuttgart: Klett-Cotta

Davis, B. (2000) Home Fires Burning: Food, Politics and Everyday Life in World War I Berlin, Chapel Hill: The University of North Carolina Press 2000.

Davies, B. (2007), The Personal is Political: Gender, Politics, and Political Activism in Modern German History, in K. Hagemanand and J. H. Quataert (Eds), Gendering Modern German History: Rewriting Historiography, New York-Oxford: Berghahn, pp.107-127

Dollenmaier, V. and Berger, U. (Eds) (2008) Glamour!: Das Girl wird feine DameFrauendarstellungen in der späten Weimarer Republik, Leipzig: E. Seemann

Elsaesser, T. (1999) Das Weimarer Kino - aufgeklärt und doppelbödig, Berlin: Vorwerk 8 Verlag 
Elsaesser, T. (2002) Filmgeschichte und frühes Kino: Archäologie eines Medienwandels, München: Ed. Text und Kritik

Elsaesser, T. and Weder, T. (Ed) (1996), A Second Life: German Cinema's First Decades, Amsterdam: Amsterdam University Press

Föllmer, M. (2005) 'Auf der Suche nach dem eigenen Leben: Junge Frauen und Individualität in der Weimarer Republik', in M. Föllmer and R. Graf (Eds), Die "Krise" der Weimarer Republik, Campus, Frankfurt am Main, New York, pp. 287-318

Francke, L. (1994) Script Girls: Women Screenwriters in Hollywood, London: British Film Institute

Ganeva, M (2013) 'Ruth Goetz', in Jane Gaines, Radha Vatsal, and Monica Dall' Asta (Eds) Women Film Pioneers Project. Center for Digital Research and Scholarship, New York: Columbia University Libraries [online]. Available at https://wfpp.cdrs.columbia.edu/pioneer/ccp-ruth-goetzl. Accessed 2 September 2015

Gebhardt, M (2006) ,Geschlechtergeschichte“ [online], 18 October. Available at http://www.hsozkult.de/debate/id/diskussionen-824. Accessed 13 September 2015

Goetz, R. and Strassburger, H. (1930), Lehrbuch der Schönheit. Das Buch der neuzeitlichen Gesundheits- und Schönheitspflege, Berlin: Peter J. Oestergaard Verlag

Haase, B. (2008) "'Metamorphose des Girl": Tendenzen der Damenmode in der späten Weimarer Republik', in V. Dollenmaier and U. Berger (Eds), Glamour!: Das Girl wird feine DameFrauendarstellungen in der späten Weimarer Republik, Leipzig: E. Seemann, pp. 27-44

Hales, B. (2007) 'Projecting Trauma: The Femme Fatale in Weimar and Hollywood Film Noir', Women in German Yearbook, 23, 224-243

Hall, S. F. (2009) 'Gender, Space and Economics in G.W. Pabst The Joyless Street (1925)', in N. W. Isenberg (Ed), Weimar Cinema: An Essential Guide to Classic Films of the Era, New York: Columbia University Press, pp. 135-155

Hagemann, K. (2007) 'From the Margins to the Mainstream? Women's and Gender History in Germany' Journal of Women's History 19:1, 193-199

Heinsohn, K and Kemper, C (2012) 'Geschlechtergeschichte: Version: 1.0' [online], 4 December. Available at http://docupedia.de/zg/Geschlechtergeschichte?oldid=106423. Accessed 3 Sepember 2015

Hepp, M. (1985) Die Ausbürgerung deutscher Staatsangehöriger: Bd. 2 Namenslisten/Index, Berlin: De Gruyter

Herminghouse, P. and Mueller, M. (1997) 'Introdction. Looking for Germania', in P. Herminghouse and M. Mueller (Eds), Gender and Germanness. Cultural Productions of Nation, ProvidenceOxford: Berghahn Books, pp. 1-20

Huerkamp, C. (1996) Bildungsbürgerinnen. Frauen im Studium und akademischen Berufen 19001945, Göttingen: Vandenhoeck \& Ruprecht

Hurst, F. (2006) 'An Author is the Person Who Wrote the Story? (1929)', in A. Lant and I. Periz (Eds), Red Velvet Seat: Women's Writings on the First Fifty Years of Cinema, London-New York: Verso, pp. 651-653 
Isenberg, N. W. (Ed) (2009) Weimar Cinema: An Essential Guide to Classic Films of the Era, New York: Columbia University Press

Johnston, C. (1999) 'Women's cinema as a counter-cinema' In S. Thornham (eds), Feminist Film theory. A Reader, Edinburgh: Edinburgh University, pp. 31-40

Kasten, J. (1990) Film schreiben: Eine Geschichte des Drehbuchs, Wien: Hora

Koonz, C. (1976a) 'Nazi Women Before 1933: Rebels Against Emancipation', Social Science Quarterly, 56:4, 553-563

Koonz, C. (1976b) 'Conflicting Allegiances: Political Ideology and Women Legislators in Weimar Germany', Journal of Women in Culture and Society, 1, 663-683

Korte, H. (1978) 'Vom Kinematographen zur Nationalen Propaganda: Zur Entwicklung des frühen deutschen Films', in H. Korte (Ed), Film und Realität in der Weimarer Republik, München-Wien: Carl Hansa, pp. 13-89

Kocka, J. (1977) Angestellte zwischen Faschismus und Demokratie: Zur politischen Sozialgeschichte der Angestellten: USA 1890-1940 im internationalen Vergleich, Göttingen: Vandenhoeck and Ruprecht

Kosta, B. (1997) 'Rape, Nation and Remembering History: Helke Sander's Liberator Take Liberties', in P. Herminghouse and M. Mueller (Eds), Gender and Germanness. Cultural Productions of Nation, Providence-Oxford: Berghahn Books, pp. 217-231

Makela, M. (2015) 'Rejuvenation and Regen(d)aration: Der Steinachfilm, Sex Glands and WeimarEra Visual Literary Culture', German Studies Review, 38:1, 35-62

Maltby, R. (2011), New Cinema Histories, in Maltby, D. Biltereyst and P. Meers (Eds), Explorations in New Cinema History: Approaches and Case Studies, Malden: Wiley-Blackwell, pp. 4-40

Marhoefer, L. (2011) 'Degeneration, Sexual Freedom, and the Politics of Weimar Republic; 19181933', German Studies Review, 34:3, 529-549

Marion, F. (2006) 'Why Do They Change the Stories in the Screen? (1926)', in A. Lant and I. Periz (Eds), Red Velvet Seat: Women's Writings on the First Fifty Years of Cinema, London-New York: Verso, pp. 648-651

Mccormick, R. W. (2009) 'Coming out of the Uniform: Political and Sexual Emancipation in Leontine Sagan's Mädchen in Uniform (1931)', in N. W. Isenberg (Ed), Weimar Cinema: An Essential Guide to Classic Films of the Era, New York: Columbia University Press, pp. 271-290

N. N. (2006a) 'Feminine Sphere in the Field of Movies is Large Indeed (1919). Interview with Clara Beranger.', in A. Lant and I. Periz (Eds), Red Velvet Seat: Women's Writings on the First Fifty Years of Cinema, London-New York: Verso, 654f

N. N. (2006b) 'Women Scenario Writer. Interview with Clara Beranger (1918)', in A. Lant and I. Periz (Eds), Red Velvet Seat: Women's Writings on the First Fifty Years of Cinema, London-New York: Verso, $653 f$

Nelmes J. and Selbo, J. (Eds.) (2015), Women Screenwriters: An International Guide, Basingstoke: Palgrave Macmillan 
Norden, M. F. (1995) 'Women in Early Film Industry', in J. Staiger (Ed), The Studio System, New Brunswick-New Jersey: Rutgers University Press, pp. 187-199

Sassenberg, M. (2004) Selma Stern (1890-1981): Das Eigene in der Geschichte: Selbstentwürfe und Geschichtsentwürfe einer Historikerin, Tübingen: Mohr Siebeck

Scheck, R (2004), Mothers of the Nation: Right-Wing Women in Weimar Germany, New YorkLondon: Bloomsbury Academic

Schmidt-Waldherr, H. (1987) Emanzipation durch Professionalisierung? Politische Strategien und Konflikte innerhalb der bürgerlichen Frauenbewegung während der Weimarer Republik und die Reaktion des bürgerlichen Antifeminismus und des Nationalsozialismus, Frankfurt am Main: Materialis Verlag

Scholz, J. (2014) 'Professionalisierung des Drehbuchautors: Hollywood und das kommunistische Europa im Vergleich', in D. Müller and H. Siegrist (Eds), Professionen, Eigentum und Staat. Europäische Entwicklungen im Vergleich - 19. und 20. Jahrhundert, Göttingen: Wallstein, pp. 298327.

Scholz, J. (2015) ,Der Drehbuchautor in den USA und Deutschland im 20. Jahrhundert. Zur Professionalisierung eines modernen Kreativ- und Medienberufs', Medien \& Zeit, 30:1, 17-29.

Scholz, J. (2016), Der Drehbuchautor: USA-Deutschland. Ein historischer Vergleich, Bielefeld: transcript 2016 (=Histoire).

Schwarz, A. (1994) Der geschriebene Film: Drehbücher des deutschen und russischen Stummfilms. zugl. Univ. Diss. 1993, München: diskurs film

Sharp, I. (2004) 'Riding the Tiger: Ambivalent Images of the New Woman in the Popular Press of Weimar Republic', in A. Heilmann and M. Beetham (Eds), New Woman Hybridities: Femininity, Feminism and International Consumer Culture, 1880-1930, London-New York: Routledge, pp. 118141

Siegrist, H. (2003) 'From Divergence to Convergence. The Divided German Middle Class, 19452000', in O. Zunz, L. Schoppa and N. Hiwatari (Eds), Social Contract Under Stress: The Middle Classes of America, Europe, and Japan at the Turn of the Century, New York: Sage, pp. 21-46

Sutton, K. (2011) The Masculine Woman in Weimar Germany, New York: Berghahn Books

Trimborn J. (2002), Riefenstahl: Eine deutsche Karriere, Berlin: Aufbau

Wager, J. (1999) Dangerous Dames: Women and Representation in the Weimar Street Film and Film Noir, Athens: Ohio University Press

Wagner, H. (2007) Die Prostituierte im Film: Zum Verhältnis von Gender und Medium, Bielefeld: transcript

Weniger, K. (2011) 'Es wird im Leben dir mehr genommen als gegeben...' Lexikon der aus Deutschland und Österreich emigrierten Filmschaffenden 1933 bis 1945: Eine Gesamtübersicht, Hamburg: Acabus Verlag

Wirsching, A. (2000) Die Weimarer Republik: Politik und Gesellschaft, München: Oldenbourg 
Yezierska, A. (2006) 'This is What \$10,000 Did to Me (1925)', in A. Lant and I. Periz (Eds), Red Velvet Seat: Women's Writings on the First Fifty Years of Cinema, London-New York: Verso, pp. 643-648

Dr Juliane Scholz is a postdoctoral cultural and media historian. She was senior researcher and lecturer at the cultural studies institute of the University Leipzig. In 2014 she gained her PhD with a dissertation on the professional history of screenwriters in the USA and in Germany. From 2010 until 2013 she held a dissertation scholarship from the „German National Academic Foundation”. She holds a PhD degree in comparative modern cultural and social history. She was a member of the international doctorate program Graduate School “Global and Area Studies” of the "Research Academy Leipzig”. Her research areas include modern social and cultural history of eastern and central Europe and the United States; migration and exile studies and film and TV history.

Email: jscholz@uni-leipzig.de 